\title{
“Foreigners" IN MODERN SWITZERLAND. IMMIGRATION ISSUES IN FEDERAL POPULAR VOTES AFTER 2000
}

\author{
„Овсу” WE WSPóŁCZESNEJ SZWAJCARII. \\ ProblematyKa IMIGRANCKA W REFERENDACH \\ FEDERALNYCH PO 2000 ROKU
}

\begin{abstract}
Switzerland did not become an immigrant country until the end of the $19^{\text {th }}$ century. Since then, the percentage of foreigners in this country has grown quite quickly and by 2021 it had exceeded $25 \%$.

Conservative groups are trying to counteract such a significant presence of immigrants in Swiss society, including the use of the popular vote. In the period 2000-2021, a total of 16 votes were held on matters relating to foreigners. The most talked about popular votes concerned the ban on the building of minarets (2009) and the ban on covering the face in public places (2021). Swiss society does not have an unequivocal attitude towards immigrants. Some popular votes end in their favour, and some do not.
\end{abstract}

\section{STRESZCZENIE}

Szwajcaria stała się krajem imigracyjnym dopiero pod koniec XIX w. Od tego czasu odsetek obcokrajowców w tym państwie rósł dosyć szybko, by osiągnąć w $2021 \mathrm{r}$. ponad $25 \%$. Środowiska konserwatywne starają się przeciwdziałać tak znacznej obecności imigrantów w społeczeństwie szwajcarskim, m.in. poprzez referenda powszechne. W latach 2000-2021 odbyło się 16 głosowań w sprawach dotyczących 
obcokrajowców. Najgłośniejsze z nich to referendum w sprawie zakazu budowania minaretów (2009) i zakazu zakrywania twarzy w miejscach publicznych (2021). Społeczeństwo szwajcarskie przejawia ambiwalentną postawę wobec imigrantów.

KEYWORDS: Switzerland, popular vote, immigration, foreigners, asylum seekers.

SŁOWA KLUCzowe: Szwajcaria, referendum, imigracja, obcy, azylanci.

\section{REFERENDUM POWSZECHNE W PRAKTYCE ŻYCIA POLITYCZNEGO SZWAJCARII}

Referenda powszechne (niem. Volksabstimmung) to często używane narzędzie demokracji bezpośredniej w Szwajcarii (Linder, 2011). Od 1848 r. Szwajcarzy decydowali przy urnach w różnych sprawach dotyczących ich kraju już 315 razy (https://www.admin.ch/gov/de/start/dokumentation/ abstimmungen.html). Korzenie tego prawa tkwią w późnym średniowieczu, w instytucji tzw. Landsgemeinde, która przetrwała do dnia dzisiejszego jedynie w dwóch kantonach: Glarus i Appenzell Innerrhoden. W innych kantonach wybierano prostsze rozwiązanie w postaci głosowania przy urnach, stosowane już w tych kantonach Konfederacji, które z uwagi na swą wielkość nie wykształciły formuły bezpośrednich spotkań. Bywało też, że odchodzono od Landsgemeinde z powodu uzyskania przez kobiety praw wyborczych (1971), a co za tym idzie - podwojenia się liczby potencjalnych uczestników zebrań, których nie były już w stanie pomieścić wykorzystywane do tego place (Stadler, 2021; Vatter, 2011, s. 28-71).

Początkowo referenda musiały być zarządzane w przypadku proponowanej rewizji lub poprawek do konstytucji oraz w przypadku inicjatywy ludowej odnośnie do całkowitej rewizji ustawy zasadniczej (Wolf, 2011, s. 15). W późniejszych latach zakres i warunki przeprowadzania referendum powszechnego były kilkakrotnie zmieniane. Od 1874 r. dopuszczono także możliwość tzw. referendum fakultatywnego w odniesieniu do całości legislacji. Każda ustawa przyjęta przez parlament mogła zostać skierowana do potwierdzenia lub odrzucenia w referendum, o ile obywatelski komitet referendalny zbierze w tej sprawie przez trzy miesiące przynajmniej 50 tys. podpisów lub zażąda tego co najmniej 8 kantonów. Od 1977 r. wydłużony został 
do 18 miesięcy okres zbierania podpisów, a także podwyższona do 100 tys. ich liczba, wszystko to jako rezultat przyznania kobietom prawa do udziału w wyborach (Florkowska, 2013). Natomiast od 1891 r. istnieje także możliwość tzw. ludowej inicjatywy konstytucyjnej - obywatele mogą złożyć wniosek o zmianę zapisu konstytucyjnego w wybranej sprawie, jeśli tylko wniosek taki poprze co najmniej 50 tys. osób (po 1977 r. warunek ten został zmieniony analogicznie do referendum fakultatywnego: 100 tys. podpisów zebranych w ciągu 18 miesięcy).

Terminy referendów ustala się obecnie z dużym, prawie dwudziestoletnim wyprzedzeniem (https://www.bk.admin.ch/ch/d/pore/va/vab_1_3_3_1.html).

\section{IMIGRANCI W SPOEECZEŃSTWIE SZWAJCARSKIM}

Przez sześć pierwszych wieków swojej historii Szwajcaria raczej dostarczała migrantów do sąsiednich krajów, niż ich przyjmowała. Po raz pierwszy dodatnie saldo migracji odnotowano dopiero w 1890 r. Od tego czasu odsetek imigrantów w społeczeństwie szwajcarskim rósł prawie nieprzerwanie, z nielicznymi wyjątkami w okresach wojen lub kryzysów gospodarczych. Obecnie wynosi on ponad $25 \%$. Składają się na to dwie grupy przyczyn: ekonomiczna i polityczna.

Pierwsza grupa ma związek z wysokim poziomem rozwoju gospodarczego Szwajcarii, co w naturalny sposób przyciąga imigrantów ekonomicznych, początkowo z krajów sąsiednich, ale od kilku dekad także z odległych rejonów Europy i świata. Druga grupa przyczyn intensyfikacji strumienia imigrantów bierze się z faktu politycznej neutralności Szwajcarii. Tradycyjnie już kraje neutralne są predestynowane do większej otwartości na osoby poszukujące azylu.

Głównym powodem, dla którego w dzisiejszej Szwajcarii mieszka ponad 2,1 mln imigrantów (określanych też jako Ausländer - obcokrajowcy, bądź Fremde - obcy), są względy ekonomiczne. Ale liczba ubiegających się o azyl w tym kraju także zwiększa się bardzo znacząco. Należy zaznaczyć, że do końca lat 70. XX w. azylanci nie stanowili problemu społecznego w sensie liczby przybywających do Szwajcarii cudzoziemców. W latach 60. i 70. składano od kilkuset do ok. tysiąca podań o azyl rocznie (Piguet, 2006, s. 97; Porębski, 2010, s. 94). Sytuacja uległa istotnej zmianie w roku 1980. Jak 
podaje światowy portal statystyczny Statista, obecnie w Szwajcarii zarejestrowanych jest ponad 67 tys. azylantów, podczas gdy jeszcze dziesięć lat wcześniej było ich nieco ponad 25 tys. (Anzahl der anerkannten Flüchtlinge in der Schweiz von 2011 bis 2021, https://de.statista.com/statistik/daten/studie/ 462131/umfrage/anerkannte-fluechtlinge-in-der-schweiz/).

\section{ProbleM OBCOKRAJOWCÓW W REFERENDACH FEDERALNYCH SZWAJCARII}

Wysoki i wciąż rosnący odsetek obcokrajowców w społeczeństwie szwajcarskim sprawia, że w niektórych środowiskach ta sytuacja budzi niepokój o możliwe zagrożenie dla porządku społecznego. Drogą do wyrażenia postaw wobec obcokrajowców stają się w naturalny sposób referenda organizowane na bazie zasady konstytucyjnej inicjatywy ludowej lub referendum fakultatywnego. W latach 1970-1999 odbyło się 11 głosowań w tego typu sprawach. Pierwsze z nich, nazywane od nazwiska wnioskodawcy Inicjatywa Schwarzenbacha (7 czerwca 1970 r.), dotyczyło żądania obniżenia odsetka obcokrajowców w każdym kantonie do 10\%, z wyjątkiem Genewy, gdzie odsetek ten mógłby sięgnąć $25 \%$. Wniosek odrzucono niewielką większością głosów przeciwnych (54:46), przy udziale 75\% uprawnionych do głosowania. Tak liczny udział w referendach rzadko się w Szwajcarii zdarza.

Wspomniane 11 głosowań w sprawach obcokrajowców dotyczyło w istocie dwóch rodzajów spraw. Po pierwsze, starano się przeciwstawić zjawisku tzw. Überfremdung, czyli nadmiernej - zdaniem wnioskodawców - obecności „obcych” w społeczeństwie i doprowadzić do jej obniżenia. Zazwyczaj wnioski te były w referendach odrzucane. Po drugie, podejmowano starania o takie zmiany w obowiązującym prawie azylowym i ustawie o obcokrajowcach (Ausländergesetz), które wzmocniłyby możliwości walki z nielegalną imigracją i nagminnym nadużywaniem prawa do azylu.

Należy dodać, że nasilenie postaw antyimigranckich obserwowane było w latach 80. i jest ponownie zauważalne obecnie nie tylko w Szwajcarii, ale także w innych krajach zachodnioeuropejskich, które przyjęły wielokulturowość jako centralną wartość tożsamości narodowej (Jetten, Mols, Postnes, 2015, s. 1). 


\section{OBCOKRAJOWCY W SZWAJCARSKICH REFERENDACH POWSZECHNYCH W LATACH 2000-2021}

\section{Referendum z 24 września 2000 r.: „O regulację imigracji”}

Komitet referendalny wysunął żądanie szybkiego zmniejszenia odsetka obcokrajowców z 19,3\% do poziomu 18\%. Ponadto nowe przepisy miałyby umożliwiać deportację oraz pozbawiane finansowego wsparcia osób nieposiadających pozwoleń na pobyt lub osiedlenie się. Argumentując swoje żądania, komitet referendalny wskazywał na ciągły wzrost odsetka obcokrajowców w Szwajcarii, wśród których coraz więcej jest osób słabo wykształconych, które przybywają z krajów nienależących do Unii Europejskiej (dalej: UE) lub EFTA.

Rząd zachęcał obywateli do odrzucenia wniosku, wskazując, iż obcokrajowcy są niezbędni dla szwajcarskiej gospodarki. Sztywne ustalenie wielkości odsetka imigrantów oznaczać będzie poważne trudności dla tych gałęzi przemysłu i usług, w których obcokrajowcy są nie do zastąpienia przez rodowitych Szwajcarów. Ponadto pod znakiem zapytania staną dwustronne umowy pomiędzy Szwajcarią a UE oraz humanitarna polityka azylowa Konfederacji.

W głosowaniu powszechnym wniosek „O regulację imigracji” został odrzucony przez naród większością 63,8\% głosów (Volksabstimmung vom 24.09.2000, https://www.bk.admin.ch/ch/d/pore/va/20000924/index.html).

\section{Referendum z 4 marca 2001 r.: „TAK dla Europy”}

Kwestie europejskie były już wcześniej poddawane pod głosowanie w roku 1992 (Volksabstimmung vom 6.12.1992, https://www.bk.admin.ch/ch/d/ pore/va/19921206/index.html) oraz w roku 1997 (Volksabstimmung vom 8.06.1997, https://www.bk.admin.ch/ch/d/pore/va/19970608/index.html). Jednak dopiero wniosek o podjęcie przez Szwajcarię umów dwustronnych z Unią spotkał się w roku 2000 z życzliwym przyjęciem suwerena.

Komitet referendalny, który wystąpił z wnioskiem o przystąpienie Szwajcarii do UE, zwracał uwagę na to, że postępuje proces wzajemnego zbliżania się krajów europejskich oraz promowania takich wartości jak praworządność, solidarność, demokracja. Członkostwo w Unii wzmocniłoby suwerenność Szwajcarii i demokrację, a także więzy z sąsiadami i bezpieczeństwo tego kraju. 
Rząd i parlament odniósł się do tych argumentów sceptycznie, wskazując, że istotny jest przebieg rozmów, a nie sugerowanie od początku, jak mają się one zakończyć. Rząd nie wyklucza członkostwa Szwajcarii w UE, ale rozpocząć należy od zakreślenia obszaru i warunków debaty (Erläuterungen des Bundesrates, https://www.bk.admin.ch/ch/d/pore/va/20010304/index.html).

Ostatecznie 76,8\% uczestników referendum z 4 marca 2001 r. „TAK dla Europy" wypowiedziało się przeciwko inicjatywie rozpoczęcia rozmów o akcesji (Volksabstimmung vom 4.03.2001, https://www.bk.admin.ch/ch/d/pore/ va/20010304/index.html).

\section{Referendum z 24 listopada 2002 r.: „Przeciwko nadużywaniu prawa azylowego"}

Wniosek o zaostrzenie prawa azylowego był już dwukrotnie poddawany pod głosowanie: w 1996 i 2000 r., za każdym razem spotykając się z negatywną odpowiedzią obywateli.

Tym razem komitet referendalny domagał się niewpuszczania azylantów przybywających z innego bezpiecznego kraju oraz obniżenia kosztów pomocy socjalnej, jaka jest im (oraz osobom tzw. „czasowo przyjętym”) udzielana w Szwajcarii.

Rząd i parlament zwracał uwagę, że takie postawienie sprawy nie rozwiązuje istotnego problemu - co dalej robić z tymi osobami? Na dodatek reputacja Szwajcarii jako kraju tradycyjnie humanitarnego będzie wystawiona na szwank, podobnie jak jej współpraca $z$ krajami sąsiednimi.

Naród bardzo niewielką większością głosów (50,1\%) wniosek odrzucił (Volksabstimmung vom 24.11.2002, https:/www.bk.admin.ch/ch/d/pore/ va/20021124/index.html).

\section{Referendum z 26 września 2004 r.: „O ułatwioną naturalizację obcokrajowców 2. i 3. pokolenia” (2 wnioski)}

Tym razem $\mathrm{z}$ wnioskiem wystąpił rząd, który dostrzegał poważne mankamenty w procedurach naturalizacyjnych w Szwajcarii - zwłaszcza ich długotrwałość i kosztowność. Większość kantonów już wprowadziła u siebie proponowane rozwiązania, teraz chodziłoby o ich rozszerzenie na całą Konfederację. Propozycje rządowe były następujące: 
A) Dzieci imigrantów miałyby spełnić niezbyt trudne w realizacji warunki dla uzyskania obywatelstwa: minimum 5 lat uczęszczania do obowiązkowej szkoły, minimum 2 lata pobytu w danej gminie, znajomość języka, niekaralność, posiadanie prawa do legalnego pobytu Szwajcarii.

B) Wnuki imigrantów: jeśli przynajmniej jedno z rodziców wyrastało w Szwajcarii, to naturalizacja dokonywałaby się automatycznie.

Obydwa wnioski zostały odrzucone większością 56,8\% głosów (Volksabstimmung vom 26.09.2004, https://www.bk.admin.ch/ch/d/pore/va/20021124/ index.html).

\section{Referendum z 24 września 2006 r.: „Prawo o obcokrajowcach (Ausländergesetz) oraz zmiana prawa azylowego" (2 wnioski)}

Dotychczasowa ustawa o obcokrajowcach obowiązywała w Szwajcarii od 1934 r. Istotą pierwszego wniosku referendalnego było przyjęcie nowej ustawy (Ausländergesetz), która lepiej uwzględniałaby zmieniony kontekst polityczny i kulturowy.

Rząd wnioskował o przyjęcie nowej ustawy, zwracając uwagę na nową sytuację w Europie (UE, strefa Schengen) oraz na potrzebę ograniczenia dostępu do rynku pracy osobom spoza UE/EFTA (z wyjątkiem wybitnych specjalistów), a także na potrzebę ułatwienia integracji imigrantów, na wyeliminowanie nielegalnego zatrudnienia, fikcyjnych małżeństw i przemytu. Co się zaś tyczy prawa azylowego, będącego przedmiotem drugiego wniosku, to wskazywano na spory obszar jego nadużyć.

Komitety referendalne, których zawiązało się kilka, podkreślały, że głosowana ustawa dyskryminuje osoby spoza UE i nie wspiera integracji. Natomiast zaostrzenie kryteriów azylowych uznano wręcz za nieludzkie.

Naród przyjął w referendum obydwa wnioski, każdy większością 68\% głosów (Volksabstimmung vom 24.09.2006, https://www.bk.admin.ch/ch/d/ pore/va/20060924/index.html).

\section{Referendum z 1 czerwca 2008 r.: „O demokratyczną naturalizację”}

Inicjatorzy referendum domagali się uznania, że to władze gmin winny mieć ostateczne prawo do przyznawania obywatelstwa, nie zaś władze fede- 
ralne. Kontekstem złożenia tego wniosku były dwa wyroki Sądu Federalnego z 2003 r., mocą których zmuszono gminy do przyjmowania odwołania od decyzji o odmowie naturalizacji.

Zarówno rząd, jak i parlament zachęcali do odrzucenia tego wniosku, i tak też się stało. 63,8\% głosujących oddaliło inicjatywę komitetu referendalnego (Volksabstimmung vom 1.06.2008, https://www.bk.admin.ch/ch/d/ pore/va/20080601/index.html).

\section{Referendum z 29 listopada 2009 r.: „Przeciwko budowie minaretów”}

W momencie zgłaszania inicjatywy odnośnie do zakazu budowy minaretów w Szwajcarii działały już liczne meczety, a cztery z nich miały także minarety. Jednak konflikt, jaki wybuchł przy okazji starania się lokalnej wspólnoty muzułmańskiej w Wangen o pozwolenie na budowę minaretu, rozlał się na całą Szwajcarię (Porębski 2009; Porębski, 2012; Green, 2011). Komitet referendalny podniósł kwestie wykraczające daleko poza sam projekt budowlany, twierdząc, że minarety to zapowiedź walki ze szwajcarskim porządkiem prawnym, a religijne znaczenie wieżyczek jest drugoplanowe.

Rząd i parlament już kilka miesięcy przed terminem referendum zachęcały do odrzucenia inicjatywy, argumentując swoje stanowisko możliwością zagrożenia praw podstawowych jednostki, pokoju religijnego czy zasad równego traktowania. Zwracano też uwagę na niebezpieczeństwo zamykania się grup muzułmańskich do wewnątrz, jak również na możliwe reakcje międzynarodowe, zwłaszcza ze strony UE, z którą Szwajcaria, choć nie jest członkiem tej organizacji, związana jest szeregiem umów dwustronnych.

Suweren poparł jednak inicjatywę większością 57,5\% głosów (Volksabstimmung vom 29.11.2009, https:/www.bk.admin.ch/ch/d/pore/va/20091129/ index.html), co doprowadziło do wpisania do konstytucji zakazu budowy minaretów w Szwajcarii.

Nieoczekiwany wynik referendum wywołał burzliwe echa w samej Szwajcarii, a także poza jej granicami. Niektóre kraje arabskie groziły nawet wycofaniem lokat ze szwajcarskich banków. Jednak jeszcze podczas kampanii przedreferendalnej Walter Wobmann, przewodniczący Komitetu Egerkingera, który stworzył wniosek referendalny, podkreślał, że ta społeczna inicjatywa nie jest wymierzona przeciwko islamowi jako takiemu i w żadnym stop- 
niu nie gwałci konstytucyjnej zasady wolności religijnej, czego dowodem jest istnienie w Szwajcarii setek meczetów. Chodzi natomiast o wyrażenie sprzeciwu przeciwko ekspansji politycznej muzułmanów, w tym także narzucaniu islamskiego prawa - szariatu.

Komentarze pochodzące ze środowisk naukowych wskazywały natomiast na przyczyny natury socjologicznej, które złożyły się na tak zaskakujący wynik referendum. Mówiono mianowicie o obecnym w Szwajcarii, ale także innych krajach europejskich, napięciu między etniczną a polityczną koncepcją naro$\mathrm{du}$, o braku zgody na integrację $\mathrm{z}$ imigrantami w krajach wielokulturowych, i wreszcie o bezkrytycznym utożsamieniu budowy minaretów z promowaniem skrajnych odłamów islamu (Antonsich, Jones, 2010, s. 57-62).

\section{Referendum z 28 listopada 2010 r.: „O wydalaniu obcokrajowców- -przestępców"}

Inicjatorzy referendum podnosili rosnący brak poczucia bezpieczeństwa w przestrzeni publicznej kraju oraz fakt, że sprawcami połowy przestępstw są obcokrajowcy. Remedium miałoby być automatyczne wydalanie cudzoziemców dopuszczających się czynów zakazanych bez prawa powrotu do Szwajcarii, i to niezależnie od wagi wykroczenia.

Rząd i parlament zachęcali do odrzucenia wniosku, wskazując na konieczność powiązania ciężaru sankcji z wagą wykroczenia. Proponowane w inicjatywie środki nijak się mają do problemu, który trzeba rozwiązać. W tej sytuacji rząd zgłosił własny projekt, który został poddany pod głosowanie w tym samym referendum.

Inicjatywę obywatelską poparło 52,3\% głosujących, natomiast projekt rządowy tylko 47,4\% (Volksabstimmung vom 28.11.2010, https://www.bk.admin. $\mathrm{ch} / \mathrm{ch} / \mathrm{d} /$ pore/va/20091129/index.html).

\section{Referendum z 9 czerwca 2013 r.: „O pilne zmiany w prawie azylowym”}

Tym razem inicjatorem referendum był rząd. Wobec lawinowego wzrostu liczby wniosków o azyl zaproponowano skrócenie procedury azylowej i testowanie tego rozwiązania przez dwa lata. Ponadto rząd chciałby wybudować budynki federalne z przeznaczeniem na tzw. centra azylu, dzięki którym możliwa byłaby lepsza kontrola osób, których podania o azyl zostały odrzucone. 
Komitet społeczny, zawiązany w odpowiedzi na inicjatywę rządową, wezwał do jej odrzucenia, zwracając uwagę na ciągłe zmiany w prawie azylowym, którym należałoby położyć kres. Tworzenie zaś wspominanych centrów azylu przyrównano do tworzenia w Szwajcarii obozów.

Wniosek rządowy został przyjęty w referendum większością aż 78,4\% głosów (Volksabstimmung vom 9.06.2013, https://www.bk.admin.ch/ch/d/pore/ va/20130609/index.html).

\section{Referendum z 9 lutego 2014 r.: „Przeciwko masowej imigracji”}

Komitet referendalny zaproponował wniosek o zahamowanie procesu masowej imigracji do Szwajcarii. Drogą ku temu miałoby być ustalenie rocznych kwot imigracyjnych, obejmujących także pracowników sezonowych, azylantów i osoby przybywające do kraju w ramach łączenia rodzin, nawet jeśli by to pociągnęło za sobą konieczność zerwania umów międzynarodowych. Tak drastyczne posunięcia wydają się - zdaniem autorów wniosku - konieczne, gdyż napływ imigrantów wywołuje szereg niekorzystnych zjawisk społecznych w Szwajcarii: zmianę kulturową, wypychanie Szwajcarów z rynku pracy, wzrost cen nieruchomości, wzrost przestępczości, tłok w komunikacji zbiorowej i korki na ulicach.

Rząd i parlament zachęcali do odrzucenia inicjatywy. Imigranci pełnią zbyt dużą rolę w gospodarce kraju, aby się ich pozbywać. Ponadto niezwykle groźne byłoby naruszenie umów zawartych z UE lub poszczególnymi krajami.

Naród poparł inicjatywę komitetu nieznaczną większością głosów - 50,3\% (Volksabstimmung vom 9.02.2014, https://www.bk.admin.ch/ch/d/ pore/va/20140209/index.html).

Co ciekawe, przeprowadzone badania wykazały, że obywatele Szwajcarii pochodzenia imigracyjnego uczestniczący $\mathrm{w}$ tym referendum byli równie przeciwni masowej imigracji jak obywatele o korzeniach miejscowych, tzn. tacy, których rodzice są obywatelami szwajcarskimi (Strijbis, Plavieja, 2018, s. 150). Wskazani autorzy doszukują się przyczyn tej pozornie niezrozumiałej postawy w zawiłościach drugoplanowej tożsamości Szwajcarów o pochodzeniu imigracyjnym oraz we współzawodnictwie na rynku pracy.

Inaczej uzasadniają antyimigracyjną wymowę wyniku referendum inni badacze (Abu-Hayyeh, Murray, Fekete, 2014, s. 90), wskazując na widoczną 
w Europie Zachodniej tendencję umacniania się partii prawicowych w takich krajach jak Francja, Niemcy, Norwegia czy Wielka Brytania.

\section{Referendum z 30 listopada 2014 r.: „Stop przeludnieniu - zabezpieczyć naturalne podstawy życia”}

Inicjatorzy wniosku domagali się ustalenia górnej granicy liczby imigrantów. Tym razem wniosek motywowano troską o chronienie zasobów naturalnych. Roczny przyrost ludności z prawem do stałego pobytu nie powinien przekraczać $0,2 \%$ populacji kraju.

Rząd i parlament argumentowały, że osiągnięcie takiego wskaźnika wiązałoby się z ograniczeniem strumienia imigracji o 25\%, co bardzo niekorzystnie wpłynęłoby na szwajcarską gospodarkę. Dodatkowo działania tego typu pogorszyłyby pozycję negocjacyjną kraju w stosunku do Unii Europejskiej. Natomiast poprawę stanu środowiska naturalnego można osiągnąć przy pomocy innych środków.

Naród odrzucił wniosek komitetu większością 59,2\% głosów (Volksabstimmung vom 30.11.2014, https:/www.bk.admin.ch/ch/d/pore/va/20141130/index.html).

\section{Referendum z 28 lutego 2016 r.:}

\section{„O wydalanie obcokrajowców-kryminalistów”}

Treść wniosku do złudzenia przypomina podobny wniosek, poddany głosowaniu już 28 listopada 2010 r., kiedy to sformułowane zostało drastyczne żądanie wydalania ze Szwajcarii osób, które dopuściły się czynów karalnych, nawet jeśli sąd nie wydał w tej sprawie wyroku. Waga przestępstwa i wymiar spodziewanej kary miałyby nie grać większej roli. Wydalenie oznaczałoby także wieloletni zakaz wjazdu. W przypadku przyjęcia w referendum wniosku podjęte ustalenia winny zostać wpisane do konstytucji.

Rząd i parlament zwróciły uwagę, że powyższa inicjatywa została zgłoszona w grudniu 2012 r., a więc w trakcie prac parlamentu nad realizacją wyniku wspomnianego przed chwilą referendum z listopada 2010 r. Parlament przyjął stosowną ustawę w marcu 2015 r., co nie wywołało kolejnych wniosków referendalnych. Tak więc obecny wniosek wydaje się bezpodstawny. 
Natomiast ewentualne wpisanie tego typu ustaleń do konstytucji podkopie pozycję sądów, które nie będą mogły rozpatrywać poszczególnych przypadków.

Suweren odrzucił wniosek większością 58,9\% głosów (Volksabstimmung vom 28.02.2016, https://www.bk.admin.ch/ch/d/pore/va/20160228/index.html).

\section{Referendum z 5 czerwca 2016 r.: „O zmianę prawa azylowego”}

Komitet referendalny żądał we wniosku zaprzestania udzielania bezpłatnej ochrony prawnej azylantom oraz zlikwidowania przyspieszonych procedur w centrach azylowych, powstałych w wyniku referendum $\mathrm{z}$ dnia 9 czerwca 2013 r. Ponadto domagano się wstrzymania nielegalnej imigracji ekonomicznej.

Rząd i parlament zachęcały do odrzucenia wniosku, wskazując, że powołanie do życia centrów azylowych zostało przetestowane w kantonie Zurych i najwyraźniej spełniło swoje zadanie. Koszty udzielania azylu zmniejszyły się, podobnie jak liczba odwołań od wydanych decyzji odmownych.

Naród zdecydował jednak o przyjęciu wniosku, i to dosyć dużą większością głosów - 66,8\% (Volksabstimmung vom 5.06.2016, https://www.bk.admin.ch/ch/d/pore/va/20160605/index.html).

\section{Referendum z 12 lutego 2017 r.: „O ułatwioną naturalizację obcokrajowców trzeciego pokolenia”}

Tym razem wniosek został zgłoszony przez rząd, który wskazywał, że nie chodzi o żadną automatyczną naturalizację, lecz o szybszy i łatwiejszy przebieg procedury, która tradycyjnie musiałaby się rozpocząć od wniesienia podania przez zainteresowaną osobę. Warunkiem zastosowania procedury ułatwionej naturalizacji miałyby być: dobra integracja, niekaralność, szacunek dla miejscowych wartości i dla konstytucji, znajomość języka, niezaleganie $\mathrm{z}$ podatkami, niekorzystanie z pomocy społecznej, wiek do 25 lat, urodzenie się w Szwajcarii, ukończenie pięciu lat nauki szkolnej i posiadanie pozwolenia na pobyt.

Wniosek rządu został przyjęty większością 60,4\% głosów (Volksabstimmung vom 12.02.2017, https://www.bk.admin.ch/ch/d/pore/va/20170212/ index.html). 


\section{Referendum z 27 września 2020 r.: „W sprawie masowej imigracji (inicjatywa ograniczająca)"}

Komitet referendalny domagał się wstrzymania swobodnego przepływu osób między Szwajcarią a Unią Europejską. Zdaniem autorów wniosku zbyt duży napływ osób spowodował destrukcję środowiska naturalnego, rynku pracy, instytucji społecznych i infrastruktury. Imigracja musi być kontrolowana.

Strona rządowa zachęcała do odrzucenia wniosku, wskazując, że przedłożona inicjatywa zagraża podpisanym już siedmiu bilateralnym umowom z UE (tzw. klauzula gilotyny - unieważnienie jednej umowy automatycznie pociąga za sobą unieważnienie pozostałych). Tymczasem konieczne jest kontynuowanie dwustronnych negocjacji w celu zawierania umów z Unią.

Wniosek został odrzucony większością 61,7\% głosów (Volksabstimmung vom 27.09.2020, https://www.bk.admin.ch/ch/d/pore/va/20200927/ index.html).

\section{Referendum z 7 marca 2021 r.: „O zakaz zakrywania twarzy”}

Inicjatorzy tego wniosku wskazywali, że zakrywanie twarzy jest wyrazem ucisku kobiet, a ponadto utrudnia identyfikację sprawców czynów zabronionych. Podobne zakazy zakrywania twarzy obowiązują już w kantonach Sankt Gallen i Tessyn. Przewidziano wyjątki od zakazu - nie obowiązuje on w miejscach kultu, ze względów bezpieczeństwa i przy odpowiedniej pogodzie (warunki klimatyczne).

Rząd wraz z parlamentem zdecydowanie rekomendowały odrzucenie wniosku, podnosząc, że dyskutowana kwestia jest zupełnie marginalna dla życia społecznego, a konsekwencje ewentualnego zakazu spadną przede wszystkim na turystki muzułmanki. Natomiast kobiety miejscowe, które zakrywały dotychczas twarz ze względów religijnych, pozostaną zamknięte w domach.

Nieoczekiwanie wniosek zyskał wśród uczestników referendum niewielką przewagę i przeszedł większością 51,2\% głosów (Volksabstimmung vom 7.03.2021, https://www.bk.admin.ch/ch/d/pore/va/20210307/index.html). 


\section{Podsumowanie}

Kwestii imigrantów dotyczyło aż 16 z 66 referendów przeprowadzonych w okresie 21 lat - między 2000 a 2021 r. Dla porównania: w poprzednich 30 latach, tj. w latach 1969-1999, odbyło się tylko 11 referendów w sprawach dotyczących cudzoziemców.

W analizowanym okresie referenda dotyczyły (w kolejności według liczby głosowań): kwestii azylowych (5 wniosków: 1 odrzucony, 4 przyjęte, w tym Prawo o obcokrajowcach); ułatwień w naturalizacji (4 wnioski: 3 odrzucone, 1 przyjęty); ograniczenia imigracji (3 wnioski: 2 odrzucone, 1 przyjęty); deportacji osób dopuszczających się czynów karalnych (2 wnioski: 1 przyjęty a 1 oddalony); kwestii kulturowych (2 wnioski: obydwa przyjęte - zakaz budowy minaretów z 2009 r. i zakaz zakrywania twarzy z 2021 r.); przystąpienia do UE (1 wniosek: odrzucony).

Przeprowadzona dotychczas szczegółowa analiza głosowań dotyczących imigrantów w Szwajcarii pozwala na sformułowanie kilku ogólniejszych wniosków.

Po pierwsze, postawa społeczeństwa szwajcarskiego wobec obcokrajowców jest ambiwalentna. Wyniki referendów poświęconych różnym aspektom napływu i obecności cudzoziemców raz wyrażają zrozumienie i troskę o położenie tej kategorii społecznej, a następnie prowadzą do pogorszenia ich sytuacji. Co jest tego powodem? Wydaje się, że polityka wobec „obcych” stara się zaspokoić dwie przeciwstawne grupy interesów. Z jednej strony są to interesy przedsiębiorców, którzy potrzebują siły roboczej gotowej do pracy w okresie koniunktury, ale i gotowej do wyjazdu w okresie spadku popytu. $\mathrm{Z}$ drugiej strony są to interesy środowisk narodowych, które nie godzą się na erozję typowych szwajcarskich wartości, takich jak chrześcijaństwo, państwo prawa, wolność od jakichkolwiek zewnętrznych nacisków, bezpieczeństwo, prywatność itp. Odsetek obcokrajowców w Szwajcarii, który przekracza obecnie 25\% (Alter, Zivilstand, Staatsangehörigkeit, https://www.bfs.admin. ch/bfs/de/home/statistiken/bevoelkerung/stand-entwicklung/alter-zivilstand-staatsangehoerigkeit.html\#-1262089700), uniemożliwia zaspokojenie oczekiwań konserwatywnie nastawionych części społeczeństwa. Trafnie wyraził tę sytuację wybitny szwajcarski dramaturg Max Frisch, komentując wzmożony napływ imigrantów w drugiej połowie XX w: „Wołano o siłę roboczą, a przyjechali ludzie” (Dejung, 1984, s. 165). 
Po drugie, największy sprzeciw w szwajcarskim społeczeństwie wywołują te zmiany kulturowe, które są najbardziej widoczne w przestrzeni życia codziennego. Chodzi tu o dwa wygrane przez konserwatystów referenda: w sprawie zakazu budowania minaretów (2009) i w sprawie zakazu zakrywania twarzy w miejscach publicznych (2021). Na marginesie warto dodać, że 26 września 2021 r. odbędzie się kolejne referendum o charakterze kulturowym, choć niezwiązane już z obcokrajowcami: „Nie dla »małżeństwa dla wszystkich “” (https://ehefueralle-nein.ch/). Chodzi tu o reakcję na przegłosowaną w parlamencie w grudniu 2020 r. ustawę zezwalającą na zawieranie małżeństw wszystkim parom, nie tylko heteroseksualnym, co w istotny sposób narusza określenie instytucji małżeństwa zawarte w szwajcarskim prawie cywilnym (https://www.ehe-recht.ch/). Nic więc dziwnego, że środowiska konserwatywne dążą do odrzucenia tej regulacji na drodze referendum fakultatywnego.

Po trzecie, społeczne komitety referendalne kładą największy nacisk na zachowanie tradycyjnego obrazu Szwajcarii jako kraju bezpiecznego, gdzie szanuje się porządek prawny, zaś jedyną drogą do poprawy swojej sytuacji osobistej i rodzinnej jest praca. Stąd też najczęściej formułowane wnioski referendalne przyjmują formę bardziej ideową niż praktyczno-instytucjonalną: ograniczyć odsetek obcokrajowców, nie nadużywać prawa azylowego, zmuszać obcokrajowców-przestępców do opuszczenia kraju, usunąć z przestrzeni publicznej elementy i symbole kulturowe obce dla Szwajcarów (zob. Referendum z 29 listopada 2009 r.: „Przeciwko budowie minaretów”, Referendum z 7 marca 2021 r.: „O zakaz zakrywania twarzy”).

Tymczasem strona parlamentarno-rządowa patrzy na problem obcokrajowców zdecydowanie bardziej przez pryzmat prawa i wymaganych przezeń procedur. Stąd też w stanowisku tej strony, oficjalnie publikowanym przed odbyciem każdego głosowania powszechnego, pojawiają się przede wszystkim takie argumenty jak: wymóg zachowania legalności procedur naturalizacyjnych, a zwłaszcza posiadanie prawa do odwołania od negatywnej decyzji naturalizacyjnej wydanej na poziomie gminy, skrócenie i uproszczenie procedur naturalizacyjnych i azylowych, reagowanie na przekraczanie bądź nadużywanie prawa przez obcokrajowców (nielegalny pobyt, fikcyjne małżeństwa, przemyt). Ponadto rząd wciąż zabiega o integrowanie cudzoziem- 
ców ze społeczeństwem oraz o respektowanie przez Konfederację Szwajcarską zawartych wcześniej umów międzynarodowych i ponoszenie zobowiązań związanych z jej statusem państwa neutralnego.

Ta odmienność perspektyw między stroną społeczną a rządową zdaje się tłumaczyć ambiwalentność ogólnego wydźwięku postawy Szwajcarów wobec obcokrajowców, o której wspomniano wyżej. Rozciągnięta w czasie gra pomiędzy suwerenem a jego instytucjonalną reprezentacją - rządem i parlamentem, które mają jednak pełnić rolę służebną wobec tego pierwszego - nie napawa optymizmem, gdy chodzi o wypracowanie spójnej polityki w kwestii imigrantów w Szwajcarii.

\section{Bibliografia}

Abu-Hayyeh, R., Murray, G., Fekete, L. (2014). Swiss referendum: flying the flag for nativism, „Race\&Class”, Vol. 56(1).

Antonsich, M., Jones, P.I. (2010). Mapping the Swiss referendum on the minarets' ban, „Political Geography”, Vol. 29, No. 2.

Dejung, Ch. (1984). Schweizer Geschichte seit 1945, Frauenfeld: Verlag Huber.

Florkowska-Frančić, H. (2013). Ewolucja głosowań federalnych $w$ Szwajcarii w latach 1848-2010. W: B. Wiśniewska-Paź (red.), Współczesna demokracja bezpośrednia. Dialog polsko-szwajcarski, Kraków: Wydawnictwo Aureus.

Green, T.H. (2011). The Resistance to Minarets in Europe, „Journal of Church and State", Vol. 52, No. 4.

Jetten, J., Mols, F., Postnes, T. (2015). Relative Deprivation and Relative Wealth Enhances Anti-Immigrant Sentiments: The V-Curve Re-Examined. W: „PLOS ONE”, October 13.

Linder, W. (2011). Blaski i cienie demokracji bezpośredniej. W: A.R. Dalby (red.), Demokracja bezpośrednia. Szwajcarska demokracja modelem dla XXI wieku?, Warszawa: Semper.

Piguet, E. (2006). Einwanderungsland Schweiz. Fünf Jahrzehnte halb geöffnete Grenzen, Bern-Stuttgart-Wien: Haupt Verlag.

Porębski, A. (2009). Spór o budowę minaretów w Szwajcarii - przyczynek do dialogu muzułmańsko-chrześcijańskiego. W: T. Paleczny, M. Banaś (red.), Dialog na pograniczach kultur i cywilizacji, Kraków: Wydawnictwo Uniwersytetu Jagiellońskiego. 
Porębski, A. (2010). Wielokulturowość Szwajcarii na rozdrożu, Kraków: Wydawnictwo Uniwersytetu Jagiellońskiego.

Porębski, A. (2012). Zróżnicowanie religijne Szwajcarii. Problem muzułmanów. W: M. Bieńkowska, A. Sadowski (red.), Polityka wielokulturowości a migracje, Białystok: Wydawnictwo Uniwersytetu w Białymstoku.

Stadler, H. (2021). Landsgemeinde. W: Historisches Lexikon der Schweiz (HLS), https://hls-dhs-dss.ch/de/articles/010239/2021-01-18/ (dostęp: 18.01.2021).

Strijbis, O., Polavieja, J. (2018). Immigrants against immigration: Competition, identity and immigrants vote on free movement in Switzerland, „Electoral Studies”, No. 56.

Vatter, A. (2011). Demokracja bezpośrednia w Szwajcarii: historia, debaty i skutki. W: M. Góra, K. Koźbiał (red.), Demokracja bezpośrednia. Szwajcarska demokracja modelem dla XXI wieku?, Warszawa: Semper.

\section{Źródła internetowe}

Alter, Zivilstand, Staatsangehörigkeit, https://www.bfs.admin.ch/bfs/de/home/statistiken/bevoelkerung/stand-entwicklung/alter-zivilstand-staatsangehoerigkeit. html\#-1262089700 (dostęp: 30.06.2021).

Anzahl der anerkannten Flüchtlinge in der Schweiz von 2011 bis 2021, https://de.statista.com/statistik/daten/studie/462131/umfrage/anerkannte-fluechtlinge-in-der-schweiz/ (dostęp: 30.06.2021).

Volksabstimmungen, https://www.admin.ch/gov/de/start/dokumentation/abstimmungen.html (dostęp: 30.06.2021).

Blanko-Abstimmungstermine, https://www.bk.admin.ch/ch/d/pore/va/vab_1_3_3_1. html (dostęp: 30.06.2021).

Nein Ehe für alle, https://ehefueralle-nein.ch (dostęp: 30.06.2021).

Rechtliche Informationen zu Eherecht, Eheschliessung und Ehe in der Schweiz, https:// www.ehe-recht.ch/ (dostęp: 30.06.2021).

Volksabstimmung vom 24.09.2000, https://www.bk.admin.ch/ch/d/pore/va/20000924/ index.html (dostęp: 30.06.2021).

Volksabstimmung vom 4.03.2001, https://www.bk.admin.ch/ch/d/pore/va/20010304/ index.html (dostęp: 30.06.2021).

Volksabstimmung vom 24.11.2002, https://www.bk.admin.ch/ch/d/pore/va/20021124/ index.html (dostęp: 30.06.2021). 
Volksabstimmung vom 26.09.2004, https://www.bk.admin.ch/ch/d/pore/va/20021124/ index.html (dostęp: 30.06.2021).

Volksabstimmung vom 24.09.2006, https://www.bk.admin.ch/ch/d/pore/va/20060924/ index.html (dostęp: 30.06.2021).

Volksabstimmung vom 1.06.2008, https://www.bk.admin.ch/ch/d/pore/va/20080601/ index.html (dostęp: 30.06.2021).

Volksabstimmung vom 29.11.2009, https://www.bk.admin.ch/ch/d/pore/va/20091129/ index.html (dostęp: 30.06.2021).

Volksabstimmung vom 28.11.2010, https://www.bk.admin.ch/ch/d/pore/va/20091129/ index.html (dostęp: 30.06.2021).

Volksabstimmung vom 29.11.2009, https://www.bk.admin.ch/ch/d/pore/va/20091129/ index.html (dostęp: 30.06.2021).)

Volksabstimmung vom 9.06.2013, https://www.bk.admin.ch/ch/d/pore/va/20130609/ index.html (dostęp: 30.06.2021).

Volksabstimmung vom 9.02.2014, https://www.bk.admin.ch/ch/d/pore/va/20140209/ index.html (dostęp: 30.06.2021).

Volksabstimmung vom 30.11.2014, https://www.bk.admin.ch/ch/d/pore/va/20141130/ index.html (dostęp: 30.06.2021).

Volksabstimmung vom 28.02.2016, https://www.bk.admin.ch/ch/d/pore/va/20160228/ index.html (dostęp: 30.06.2021).

Volksabstimmung vom 5.06.2016, https://www.bk.admin.ch/ch/d/pore/va/20160605/ index.html (dostęp: 30.06.2021).

Volksabstimmung vom 12.02.2017, https://www.bk.admin.ch/ch/d/pore/va/20170212/ index.html (dostęp: 30.06.2021).

Volksabstimmung vom 27.09.2020, https://www.bk.admin.ch/ch/d/pore/va/20200927/ index.html (dostęp: 30.06.2021).

Volksabstimmung vom 7.03.2021, https://www.bk.admin.ch/ch/d/pore/va/20210307/ index.html (dostęp: 30.06.2021). 